\title{
Surgical management of traumatic cerebrospinal fluid fistulas with associated lesions
}

\author{
Fatih Alagöz, M.D., ${ }^{1}$ Ergün Dağlıoğlu, M.D., ${ }^{1}$ Murat Korkmaz, M.D., ${ }^{2}$ Ali Erdem Yıldırım, M.D., ${ }^{1}$ \\ Özhan Merzuk Uçkun, M.D., ${ }^{3}$ Denizhan Divanlıoğlu, M.D., ${ }^{1}$ Ömer Polat, M.D., ${ }^{4}$ Ali Dalgıç, M.D., ${ }^{1}$ \\ Arif Ösün, M.D., ${ }^{2}$ Fevzi Yılmaz, M.D., ${ }^{5}$ Müge Sönmez, M.D., ${ }^{5}$ Ahmet Deniz Belen, M.D. ${ }^{1}$
}

\author{
1Department of Neurosurgery, Ankara Numune Training and Research Hospital, Ankara \\ ${ }^{2}$ Department of Neurosurgery, Kutahya Evliya Celebi Training and Research Hospital, Kutahya \\ ${ }^{3}$ Department of Neurosurgery, Yunus Emre State Hospital, Eskisehir \\ ${ }^{4}$ Department of Neurosurgery, Fatma Hatun Private Hostpital, Bolu \\ ${ }^{5}$ Department of Emergency, Ankara Numune Training and Research Hospital, Ankara
}

\begin{abstract}
BACKGROUND: Head trauma is associated with a significant risk of cerebrospinal fluid (CSF) fistula.

METHODS: In this study, it was aimed to report twenty-two cases subjected to operative intervention for otorrhea, rhinorrhea and oculorrhea with associated traumatic lesions. Majority of the cases had moderate to severe head trauma with a Glascow Coma Scale (GCS) score under 14. The study group included eleven cases with depression fractures, 6 with epidural hematomas and 4 with tension pneumocephalus.
\end{abstract}

RESULTS: Rhinorrhea was the most common presenting symptom encountered in fifteen cases; whereas, otorrhea was prominent in 7 and oculorrhea in 2 cases. Two patients having rhinorrhea also had oculorrhea and otorrhea. The patients were operated with unilateral approaches in twelve and bifrontal approaches in ten of the cases.

CONCLUSION: Early surgical intervention should be performed in cases presenting with CSF fistula and associated traumatic lesions without considering conservative management to provide an effective control of associated complications due to CSF fistulas.

Key words: CSF fistula; oculorrhea; otorrhea; rhinorrhea; surgery; trauma.

\section{INTRODUCTION}

Trauma is the most commonly encountered reason for cerebrospinal fluid (CSF) fistula. Two percent of head traumas and \%20 of skull base fractures carry the risk of traumatic CSF fistula. ${ }^{[1,2]}$ About one fifth of CSF fistulas are seen as otorrhea due to middle cranial fossa fractures and the remaining $80 \%$ is seen as rhinorrhea secondary to anterior cranial fossa fractures. ${ }^{[3,4]}$ Treatment starts at early recogni-

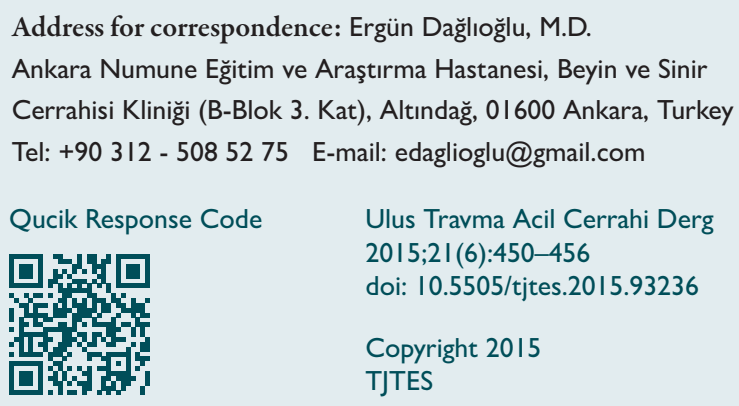

tion and verification of the exact site of leakage since infectious complications are the major causes of morbidity at acute and subacute stages. ${ }^{[1,3-5]}$ Although CSF leaks, particularly mild ones, do resolve spontaneously, some tend to persist and necessitate other treatment modalities including daily lumbar punctures or external lumbar drainage. Despite conservative measures, a portion of CSF leaks do not cease and surgical treatment should be performed. Some CSF fistula patients require urgent surgical repair due to associated pathologies. ${ }^{[6-8]}$ This group is unique in that the cases are usually subjected to moderate or severe head trauma requiring surgery due to associated lesion together with rhinorrhea, oculorrhea or otorrhea which tends to persist. Although there are conservative measures advocated for definitive treatment, appropriate timing of surgery is also crucial to prevent complications particularly in fractures involving sinuses.

In the present study, we reported our indications for urgent surgical repair of traumatic CSF fistulas via the anterior and middle cranial fossa with a specific interest on associated 
traumatic lesions like depression fractures, epidural hematomas or tension pneumocephalus.

\section{MATERIALS AND METHODS}

\section{Patient Selection}

The study included twenty-two patients admitted to Ankara Numune Education and Research Hospital in a period of five years. The patients presented with acute head trauma and associated CSF fistulas (rhinorrhea, oculorrhea and otorrhea). The study group was selected among sixty-five patients presented with traumatic CSF fistulas. All of the patients were managed conservatively (closed lumbar drainage or observation alone) before CSF fistula repair except associated lesions, which should be operated urgently, such as depression fractures, epidural hematoma, etc. ${ }^{[9]}$ Sixteen patients were male and 6 were female. Seven patients were in the pediatric $(<16$ years) and 15 cases were in the adult group with a mean age of 27 years at presentation. The patients were further classified into three groups as mild ( 5 cases with GCS score between 14 and 15), moderate (13 cases with GCS score between 8 and 13) and severe head trauma (4 cases with GCS score 7 or less). Patient characteristics on presentation and details of clinical management were summarized in Table I.

Site of the CSF fistula might not be determined accurately without CT cisternography and we relied on axial and coronal milimetric high-resolution CT scans since some of the cases were operated in an urgent manner. However, metrizamide CT cisternography was performed on a few cases operated in a delayed fashion. Surgical success was assessed clinically, and provocative tests like CT cisternography was not performed unless overt CSF fistula was detected clinically. The therapy was found to be successful at the early period if there was no recurrent CSF fistula for successive 7 days. Glasgow Outcome Scale (GOS) was also used as an adjunct measure to assess clinical success.

\section{Surgical Technique}

Wide exposure through intracranial approaches provides enough space for the removal of associated traumatic pathologies and adequate closure of the defect. If frontal and ethmoidal sinuses are involved, craniotomy should extend to frontal sinuses and cranialization with proper positioning at the operation and CSF drainage may aid in the minimization of frontal lobe retraction. Among the twenty-two cases studied in the present report, unilateral approach was performed in 12 and bilateral approach in the remaining 10 cases. A unilateral frontal or temporal craniotomy was preferred in patients with unilateral injury with otorrhea or rhinorrhea; whereas, a conventional bifrontal craniotomy was the most common procedure in bilateral approaches. Dural repair was performed in all cases either with fascia lata or galeal graft. Surgical techniques regarding the interventions were summarized in Table I.
Closure with viable or nonviable grafts can be performed. However, we suggest that nonviable fascia lata or galeal grafts are practical to use when compared to pericranium flaps especially in wide defects. Depending on our previous experience about non viable grafts, we usually notice that most of them revascularize a few months after surgery. We prefer to preserve pericranium for the viability of bone flap. Thus, we preferred surgical repair of the fistulous point with viable graft in all cases of the present study. Fibrin glue was used as an adjunctive measure almost for every case to increase the success of surgical repair. Antibiotics were given intravenously at full regimen when CSF fistula was detected and continued for 7 days (oral or intravenous) after surgical intervention.

\section{RESULTS}

On admission, seven patients had otorrhea, 15 patients had rhinorrhea and 2 patients had oculorrhea (some patients had multiple findings, a patient with oculorrhea also had rhinorrhea and a patient with otorrhea also had rhinorrhea). Seventeen patients were operated after conservative treatment while the remaining 5 cases were urgently operated for associated intracranial lesions and complications. Besides otorrhea, rhinorrhea or oculorrhea, associated pathologies were classified as linear fractures ( 8 cases), depression fracture (I I cases), Le Fort fractures ( 3 cases), epidural hematoma ( 6 cases), cerebral contusion ( 9 cases), intracerebral and subarachnoid hemorrhage (4 cases) and wound CSF fistula (I case) (some patients had multiple findings). One patient was operated in an emergent basis due to the presence of wound CSF fistula. Unilateral approach was performed in twelve patients and the remaining 10 cases were operated by bifrontal approaches with ligation of the superior sagittal sinus. All of the patients were subjected to dural repair with either fascia lata or galeal graft, however, no synthetic material was used for duraplasty. In urgently operated patients with associated lesions such as epidural hematoma, intracerebral hematoma and pneumocephalus, CSF fistula repair was done at the same operation. Depression fractures were surgically reconstructed. Among the patients with depression fractures, seven patients were also subjected to orbital reconstruction for severe orbital roof fractures. Distribution of lesion localizations was demonstrated in Table I.

At the postoperative period, meningitis (5 cases), urinary tract infection (I case), pulmonary infection (I case), deep venous thrombosis ( $I$ case), and transient diabetes insipidus ( 3 cases) were seen as complications. There was no mortality rate. Complications were managed successfully by conservative measures. All of the patients were followed up for a mean of 32 months and their last neurological examination revealed that the GOS (Glasgow Outcome Scale) score was 4 in six cases and 5 in sixteen cases.

\section{Illustrative Cases}

Case 2: A 15-year-old female patient with head trauma ad- 


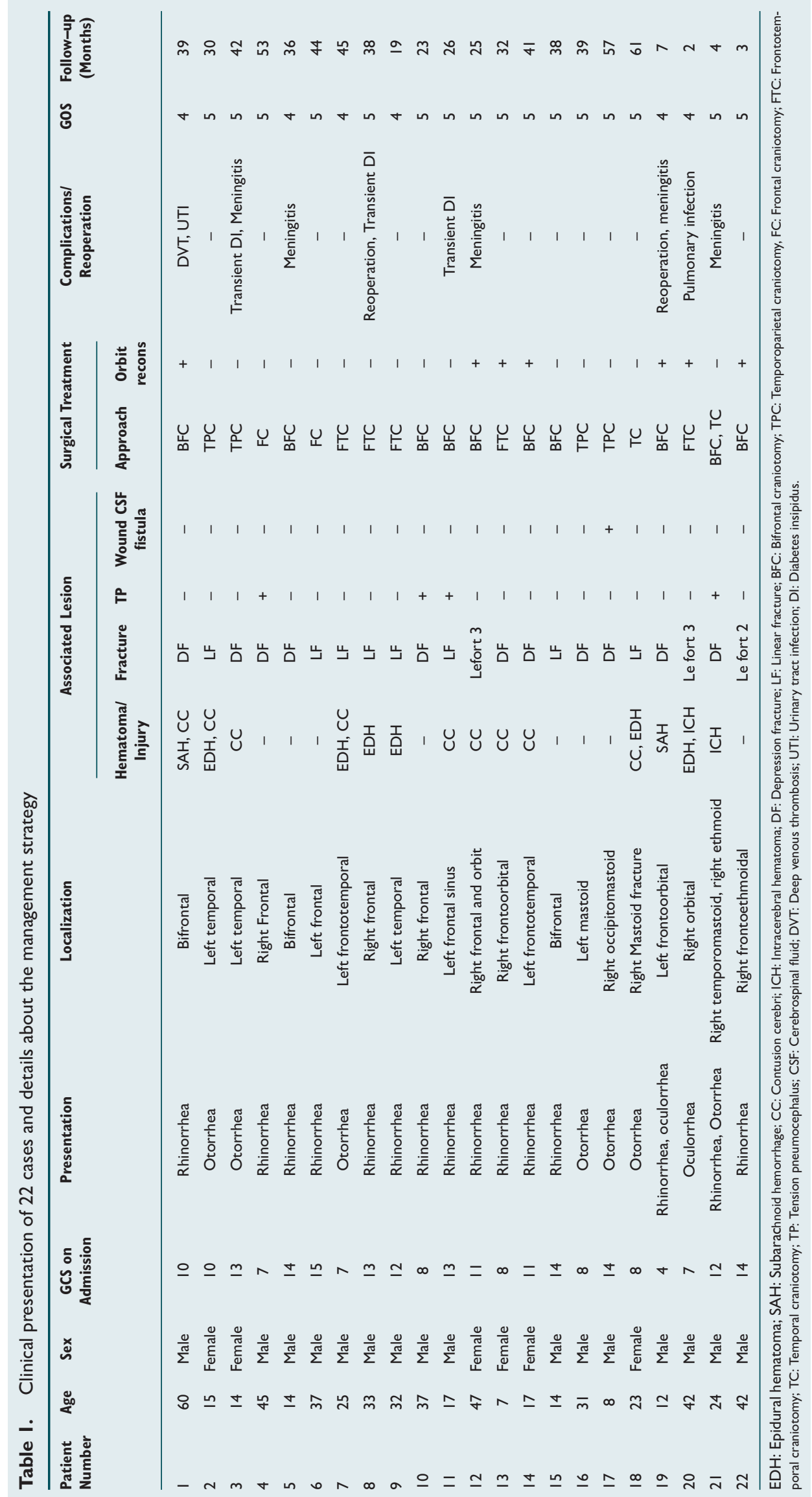



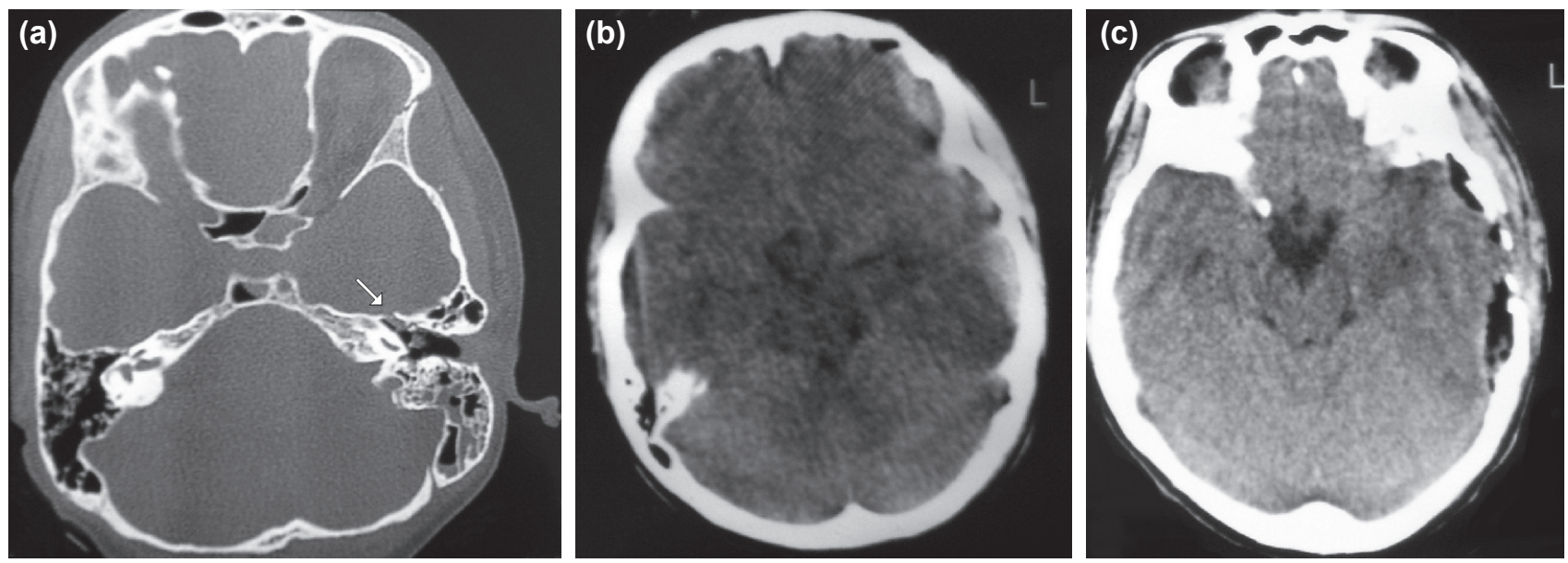

Figure 1. 15-year-old female presents with otorrhea and epidural hematoma with a GCS score of 10 on admission. (a) Axial bone window CT image shows the fracture line at the tegmental (arrow) and mastoid portion of the temporal bone as well as orbita. (b) Axial CT scan shows a growing epidural hematoma on the same side. (c) Postoperative axial CT image reveals decompression of the hematoma and better visualizations of mesencephalic cisterns.

mitted with a GCS score of 10 and otorrhea was seen at the initial examination (Table I). Axial CT (Computerized tomography) scan showed a left-sided fronto-temporal epidural hematoma, fracture lines at the orbita, temporal and occipital bones (Figs. I $a$ and $b$ ). She was operated for the evacuation of hematoma and surgical repair of otorrhea. At the operation, the defect at the tegmental portion of the temporal bone was repaired with fascia lata graft and fibrin glue. At the postoperative period, her neurological status improved significantly and she was discharged on the seventh postoperative day. There was no otorrhea on follow-up examinations and postoperative changes were noted on CT scan (Fig. Ic).

Case 4: A 40-year-old male presented with rhinorrhea, sudden loss of consciousness, tension pneumocephalus and an- terior cranial fossa fracture involving fronto-ethmoid bone (Table I). Priorly, he had been operated at another center for an unknown traumatic lesion. Axial CT image showed severe tension pneumocephalus extending from anterior cranial fossa to lateral ventricles and compressing cerebral cisterns (Fig. 2a). Right sided frontal craniotomy was performed and frontal sinus fracture was repaired with galeal graft and fibrin glue. Clinical condition improved dramatically at the early postoperative period. CSF leakage also ceased, and there was no rhinorrhea on follow-up. Postoperative axial CT image showed successful decompression of pneumocephalus (Fig. 2b).

Case II: A 17-year-old male presented with clouding of consciousness, rhinorrhea, hemiparesis and tension pneumocephalus (Table I). He had a history of head trauma 25
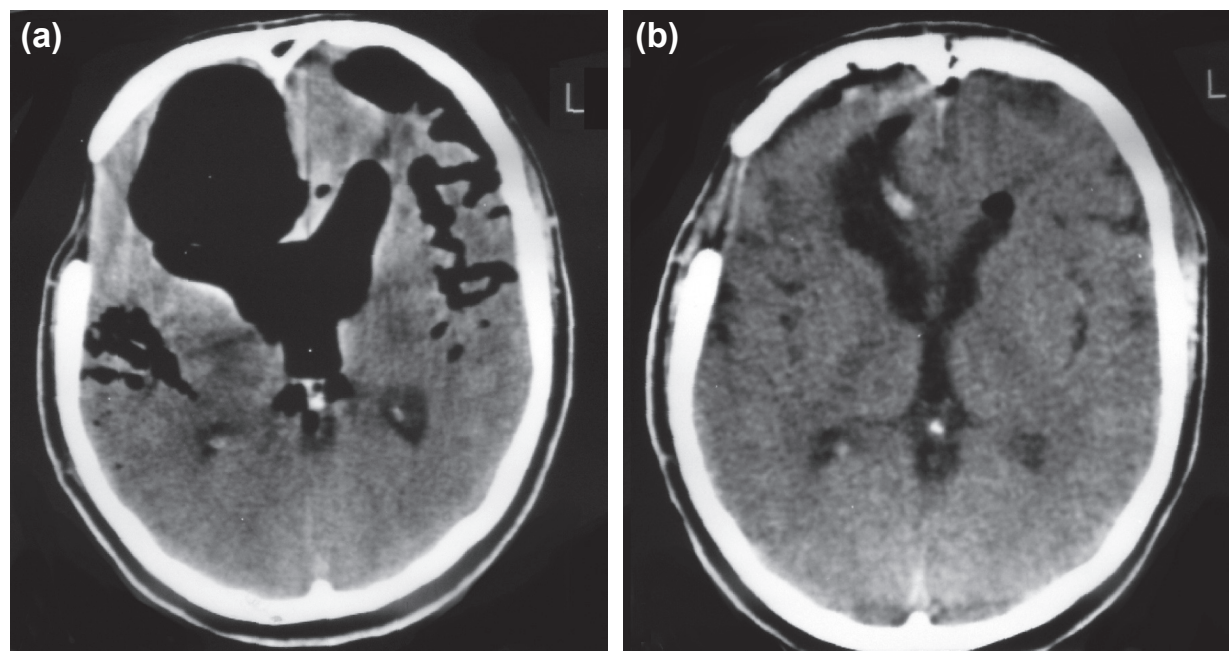

Figure 2. 40-year-old male presents with rhinorrhea and sudden loss of consciousness. Patient history revealed that he had been operated at another center for a traumatic lesion several years ago. (a) Axial CT image shows severe tension pneumocephalus extending from anterior cranial fossa to cerebral cisterns and lateral ventricles. (b) Postoperative axial CT image demonstrates almost complete resorption of pneumocephalus. 

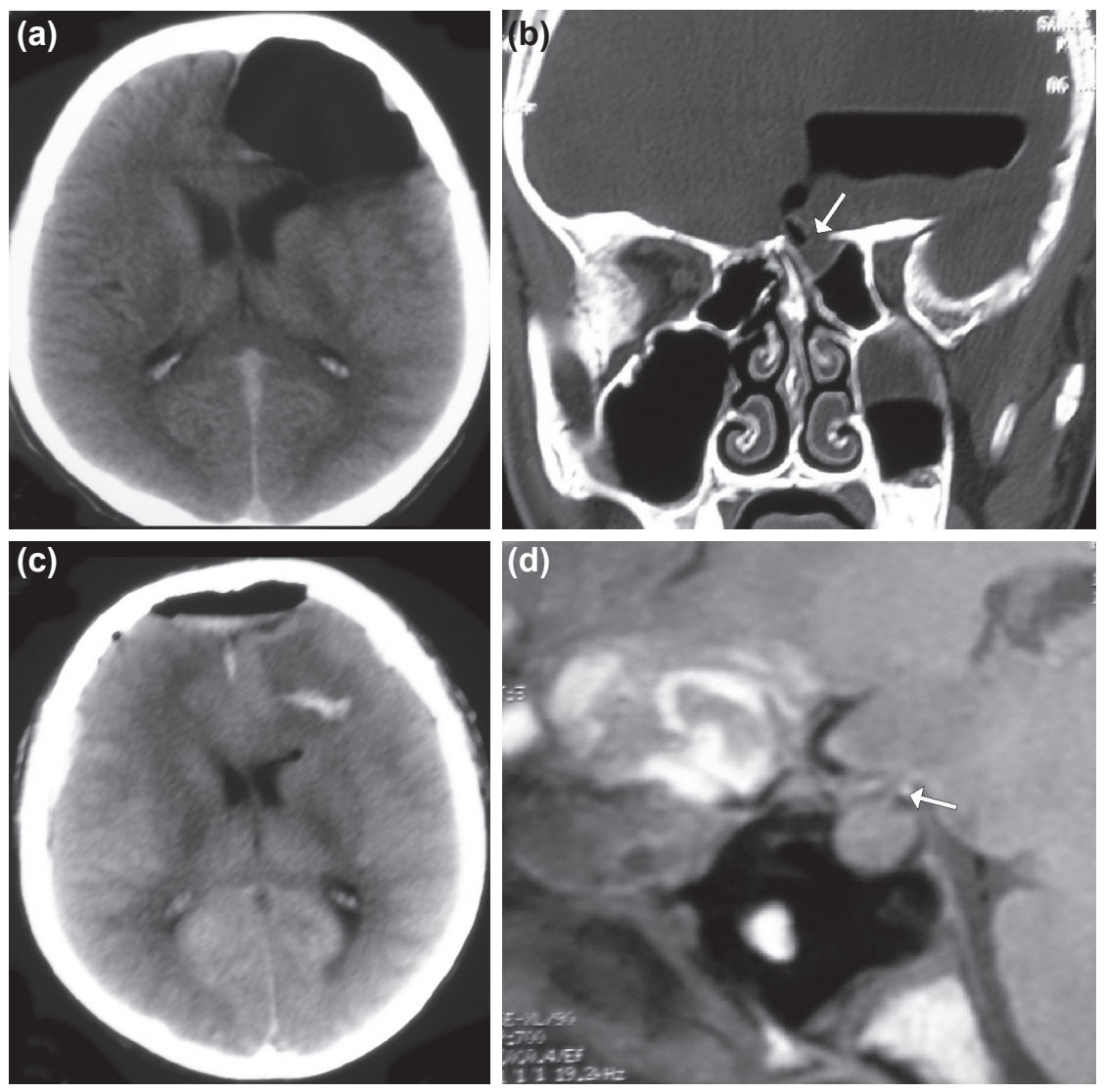

Figure 3. 17-year-old male presents with apathy, hemiparesis, rhinorrhea and tension pneumocephalus. He had a history of head trauma one month ago. At the postoperative period, the patient experienced findings of diabetes insipidus. (a) Axial CT image shows left frontal tension pneumocephalus. (b) Coronal CT scan reveals the bony defect over the ethmoid bone (arrow). (c) Postoperative axial CT image reveals disappearance of pneumocephalus with minimal hemorrhage at the operation lodge. (d) Sagittal T1-weighted MR image at the early postoperative period demonstrates hypointense changes on hypothalamopituitary axis and hardly visualized pituitary stalk.

days ago. Axial CT image showed left frontal tension pneumocephalus (Figs. 3a and b). Metrizamide CT scan could not be performed due to patient's general condition and urgency of the operation. He was operated with a bifrontal approach for the evacuation of pneumocephalus and repairing the dural defect over the anterior cranial fossa. At the operation, the dural defect extending from frontal to the posterior portion of the ethmoid bone was repaired. On the postoperative course, polyuria and severe hypernatremia were seen and desmopressin was used for diabetes insipidus treatment. Serum $\mathrm{ADH}$ (Antidiuretic hormone) level was normal; however, $\mathrm{GH}$ (Growth hormone) and cortisol levels were moderately low. CT scan showed successful resorption of pneumocephalus (Fig. 3c). Magnetic Resonance Imaging (MRI) of the sellar region didn't show any abnormalities except hypointense signals on TI-weighted MR images (Fig. 3d). Findings of diabetes insipidus resolved completely 5 months after trauma.

\section{DISCUSSION}

CSF fistula presenting with associated traumatic lesions is a challenging situation for neurosurgeons particularly due to the timing of the surgical repair. Management may be quite difficult because of a dilemma due to patient's general condition and the risk of the planned surgical approach. Tension pneumocehalus, persistent otorrhea and rhinorrhea are main indications for surgical treatment. In this study, we reported our experience regarding anterior and middle cranial fossa fractures particularly presenting with otorrhea, rhinorrhea and oculorrhea. CSF leakage is a serious condition which could be complicated with severe meningitis and pneumocephalus. It occurs when the barriers retaining CSF around the brain are breached. There are various methods advocated for the treatment of CSF fistulas. But, there is still a debate about the timing of surgical intervention. Associated lesions necessitating immediate surgical intervention is the most important factor to decide for timing of surgery. ${ }^{[10,11]}$

Conservative management strategies include elevation of head about 30-45 degrees, fluid restriction and diuretic treatment, daily lumbar punctures and intermittent or continuous lumbar drainage. If the patient is not to be operated in an emergent manner due to lack of an associated lesion, conservative treatment methods are performed under combined antibiotic prophylaxis. CSF leakage has been reported to stop 4.I days (mean value) after trauma and 5.3 days after lumbar drainage, and ratio of spontaneous cessation has been reported to be $61 \% .^{[5,8]}$ Surgical treatment should be considered in cases with leak that persists for more than one week. ${ }^{[12,13]}$ However, there are some exceptions to this principal management strategy such as high risk elderly patients, patients with diabetes mellitus and immunosuppressed condition, associated intracranial pathologies or profuse leaks. CSF leakage should be managed in these patients without any delay. ${ }^{[8,12,14]}$ Similarly, patients with severe head trauma or 
low GCS should be managed with radical surgical measures since the risk of infectious complications or neurological deterioration is quite high. ${ }^{[5,8]}$ Surgical intervention should also be considered for cases with subdural or epidural hematomas, tension pneumocephalus, depression fractures including comminuted skull base fractures or patients with severe contusion and edema. These lesions require decompressive measures, all of which limit the use of lumbar drainage or temporary lumbar punctures for CSF fistulae.

Wide exposure provides enough space for the removal of associated traumatic pathologies and adequate closure of the defect. If frontal and ethmoidal sinuses are involved, craniotomy should be extended to frontal sinuses and cranialization with proper positioning at the operation, and CSF drainage could aid in the minimization of frontal lobe retraction. Closure with viable or nonviable grafts was reported in the previous studies and there was no difference in success. ${ }^{[15]}$ However, it is our suggestion that fascia lata graft is proper to use especially in wide defects to preserve pericranium for the viability of the operative area and bone flap. Any artificial material for surgical repair was not preferred because of our prior surgical experience.

Anterior cranial fossa fractures involving cribriform plate and ethmoid or frontal sinus frequently give rise to rhinorrea and forms the second leading cause of tension pneumocephalus and surgical treatment may be required. ${ }^{[16,17]}$ Dural tear and entrapped air could be sequelae of fractures involving anterior cranial fossa via siphon effect or a Valsalva maneuver. Entrapped air is usually seen as intracerebral, subdural and intraventricular in decreasing order of frequency and could be associated with rhinorrhea or sometimes oculorrhea. Furthermore, traumatic oculorrhea is very rare, and conservative management of oculorrhea is controversial. ${ }^{[18]}$ Although there are asymptomatic and conservatively managed cases, surgical intervention is usually necessary to close the associated dural defect particularly behind the orbit and decompression of tension pneumocephalus. ${ }^{[17,19-21]}$ In evidence of acute clinical deterioration and signs of increased intracranial pressure (ICP), or pressure on adjacent cerebral tissue or ventricular wall, or presence of the Mount Fuji sign, urgent surgical intervention is indicated. ${ }^{[22]}$ Many cases present within a few weeks, several months or even years after head trauma. However, cases presenting with sudden neurological deterioration and low GCS should be immediately operated before performing a contrast enhanced CT study for the exact localization of fistula. In the present report, four cases were operated for delayed pneumocephalus, rhinorrheaotorrhea and clinical deterioration.

Anterior or middle fossa fractures are associated with a significant morbidity rate due to related complications. Trauma to the anterior and middle cranial fossa could give rise to CSF leak, and there is an increased risk for infectious complications after one week. ${ }^{[1,5,9,23]}$ However, in another report, antibiotic prophylaxis is usually ineffective for minimizing therisk of meningitis. ${ }^{[24]}$ In the present study, infection ratio was detected to be $23 \%$, which does not seem to justify our main idea of urgent surgical intervention for the prevention of early posttraumatic morbidity. The ratio seemed to be high although nearly all cases were lacking the awaiting period for conservative management. Nevertheless, the study group included eight patients with severe and six patients with moderate head trauma, which does not appear to be high.

Apart from infectious complications like meningitis, trauma itself could also cause hypopituitarism. Hypopituitarism is a well known complication of moderate to severe cerebral trauma. ${ }^{[25,26]}$ However, the condition is not associated with radiological abnormalities on regular $\mathrm{CT}$ or MR studies. Hypointense signals on $\mathrm{TI}$-weighted $\mathrm{MR}$ images of Case II were accepted as non-specific findings. $\mathrm{GH}$ and gonadal sex steroid secretion levels are very sensitive to cerebral trauma; however, deficiency of steroid and thyroid hormones would certainly have an impact on the clinical condition. ${ }^{[25]}$ Deficiency of posterior pituitary hormones could result in diabetes insipidus giving rise to metabolic problems after head trauma. ${ }^{[27,28]}$ Although the condition is transient in most of the cases, disorders of water imbalance could increase the severity of traumatic cerebral edema or neurological condition, and hence, result in increased morbidity and mortality. Awareness of the levels of pituitary hormones could assist in good clinical outcomes.

Postoperative use of lumbar drainage catheters or lumbar punctures should be reserved for cases having persistent postoperative CSF fistulas. Although lumbar drainage catheters provide minimal invasive treatment of CSF fistulae in uncomplicated cases, it may cause severe complications such as subdural hematoma, herniation, meningitis and other infectious problems.

\section{Conclusion}

The present report emphasizes the importance of early surgical intervention for head trauma with CSF fistula particularly presenting with associated lesions like depression fractures, subdural hematomas, wound CSF fistulas and pneumocephalus. Repair for CSF fistulae should not be delayed, and combined approaches both for associated lesion and fistula should not be avoided even though it bears high risk of morbidity and mortality.

Conflict of interest: None declared.

\section{REFERENCES}

1. Brodie HA, Thompson TC. Management of complications from 820 temporal bone fractures. Am J Otol 1997;18:188-97.

2. Mendizabal GR, Moreno BC, Flores CC. Cerebrospinal fluid fistula: frequency in head injuries. Rev Laryngol Otol Rhinol (Bord) 1992;113:423-5. 
3. Stenzel M, Preuss S, Orloff L, Jecker P, Mann W. Cerebrospinal fluid leaks of temporal bone origin: etiology and management. ORL J Otorhinolaryngol Relat Spec 2005;67:51-5. CrossRef

4. McCormack B, Cooper PR, Persky M, Rothstein S. Extracranial repair of cerebrospinal fluid fistulas: technique and results in 37 patients. Neurosurgery 1990;27:412-7. CrossRef

5. Friedman JA, Ebersold MJ, Quast LM. Post-traumatic cerebrospinal fluid leakage. World J Surg 2001;25:1062-6. CrossRef

6. Savva A, Taylor MJ, Beatty CW. Management of cerebrospinal fluid leaks involving the temporal bone: report on 92 patients. Laryngoscope 2003;113:50-6. CrossRef

7. Hegazy HM, Carrau RL, Snyderman CH, Kassam A, Zweig J. Transnasal endoscopic repair of cerebrospinal fluid rhinorrhea: a meta-analysis. Laryngoscope 2000;110:1166-72. CrossRef

8. Yilmazlar S, Arslan E, Kocaeli H, Dogan S, Aksoy K, Korfali E, et al. Cerebrospinal fluid leakage complicating skull base fractures: analysis of 81 cases. Neurosurg Rev 2006;29:64-71. CrossRef

9. Dalgic A, Okay HO, Gezici AR, Daglioglu E, Akdag R, Ergungor MF. An effective and less invasive treatment of post-traumatic cerebrospinal fluid fistula: closed lumbar drainage system. Minim Invasive Neurosurg 2008;51:154-7. CrossRef

10. Choi D, Spann R. Traumatic cerebrospinal fluid leakage: risk factors and the use of prophylactic antibiotics. Br J Neurosurg 1996;10:571-5. CrossRef

11. McGuirt WF Jr, Stool SE. Cerebrospinal fluid fistula: the identification and management in pediatric temporal bone fractures. Laryngoscope 1995;105:359-64. CrossRef

12. Bell RB, Dierks EJ, Homer L, Potter BE. Management of cerebrospinal fluid leak associated with craniomaxillofacial trauma. J Oral Maxillofac Surg 2004;62:676-84. CrossRef

13. Abuabara A. Cerebrospinal fluid rhinorrhoea: diagnosis and management. Med Oral Patol Oral Cir Bucal 2007;12:397-400.

14. Piek J. Surgical treatment of complex traumatic frontobasal lesions: personal experience in 74 patients. Neurosurg Focus 2000;9:2. CrossRef

15. Bhatoe HS. Missile injuries of the anterior skull base. Skull Base 2004;14:1-8. CrossRef

16. Keskil S, Baykaner K, Ceviker N, Işik S, Cengel M, Orbay T. Clinical significance of acute traumatic intracranial pneumocephalus. Neurosurg Rev 1998;21:10-3. CrossRef

17. Hotta T, Kodama Y, Yuki K, Taniguchi E, Kuroki K, Hashizume A, et al. Two cases of traumatic intracerebral pneumocephalus. [Article in Japanese] No Shinkei Geka 1994;22:259-63. [Abstract]

18. Salame K, Segev Y, Fliss DM, Ouaknine GE. Diagnosis and management of posttraumatic oculorrhea. Neurosurg Focus 2000;9:3. CrossRef

19. Oge K, Akpinar G, Bertan V. Traumatic subdural pneumocephalus causing rise in intracranial pressure in the early phase of head trauma: report of two cases. Acta Neurochir (Wien) 1998;140:655-8. CrossRef

20. Skuna S, Chaiyabud P, Pakdirat B. Subdural tension pneumocephalus following head injury: report of five cases. J Med Assoc Thai 1993;76:34552.

21. Kilincoğlu BF, Mukaddem AM, Lakadamyali H, Altinörs N. Posttraumatic tension pneumocephalus causing herniation. [Article in Turkish] Ulus Travma Acil Cerrahi Derg 2003;9:79-81.

22. Michel SJ. The Mount Fuji sign. Radiology 2004;232:449-50. CrossRef

23. Gliklich RE, Lazor JB. The subcranial approach to trauma of the anterior cranial base: preliminary report. J Craniomaxillofac Trauma 1995;1:5662.

24. Eftekhar B, Ghodsi M, Nejat F, Ketabchi E, Esmaeeli B. Prophylactic administration of ceftriaxone for the prevention of meningitis after traumatic pneumocephalus: results of a clinical trial. J Neurosurg 2004;101:757-61. CrossRef

25. Powner DJ, Boccalandro C, Alp MS, Vollmer DG. Endocrine failure after traumatic brain injury in adults. Neurocrit Care 2006;5:61-70. CrossRef

26. Schneider HJ, Kreitschmann-Andermahr I, Ghigo E, Stalla GK, Agha A. Hypothalamopituitary dysfunction following traumatic brain injury and aneurysmal subarachnoid hemorrhage: a systematic review. JAMA 2007;298:1429-38. CrossRef

27. Agha A, Thornton E, O'Kelly P, Tormey W, Phillips J, Thompson CJ. Posterior pituitary dysfunction after traumatic brain injury. J Clin Endocrinol Metab 2004;89:5987-92. CrossRef

28. Tsagarakis S, Tzanela M, Dimopoulou I. Diabetes insipidus, secondary hypoadrenalism and hypothyroidism after traumatic brain injury: clinical implications. Pituitary 2005;8:251-4. CrossRef

\section{ORİJINAL ÇALIŞMA - ÖZET}

\section{İlişkili lezyonlarla birlikte olan travmatik beyin omurilik sıvısı kaçaklarının cerrahi tedavisi \\ Dr. Fatih Alagöz, ${ }^{1}$ Dr. Ergün Dağlıoğlu, ${ }^{1}$ Dr. Murat Korkmaz, ${ }^{2}$ Dr. Ali Erdem Yıldırım, ${ }^{1}$ Dr. Özhan Merzuk Uçkun, ${ }^{3}$ \\ Dr. Denizhan Divanlıoğlu, ${ }^{1}$ Dr. Ömer Polat, ${ }^{4}$ Dr. Ali Dalgıç, ${ }^{1}$ Dr. Arif Ösün, ${ }^{2}$ Dr. Fevzi Yılmaz, ${ }^{5}$ \\ Dr. Müge Sönmez, ${ }^{5}$ Dr. Ahmet Deniz Belen ${ }^{1}$}

${ }^{1}$ Ankara Numune Eğitim ve Araştırma Hastanesi, Beyin Cerrahisi Kliniği, Ankara

${ }^{2}$ Kütahya Evliya Çelebi Eğitim ve Araştırma Hastanesi, Beyin Cerrahisi Kliniği, Kütahya

${ }^{3}$ Yunus Emre Devlet Hastanesi, Beyin Cerrahisi Kliniği, Eskişehir

${ }^{4}$ Özel Fatma Hatun Hastanesi, Beyin Cerrahisi Kliniği, Bolu

${ }^{5}$ Ankara Numune Eğitim ve Araştırma Hastanesi, Acil Kliniği, Ankara

AMAÇ: Kafa travması beyin omurilik sıvıSı (BOS) fistülü ile önemli bir ilişki gösterir.

GEREÇ VE YÖNTEM: Bu çalışmada travmaya bağı gelişen otore, rinore ve oküloresi bulunan 22 hastanının cerrahi yaklaşımı sunuldu. Hastaların büyük çoğunluğu Glaskow Koma Skalası (GKS) I4 puanın altında olan şiddetli kafa travmalı hastalardır. Bu hastaların I I'inde depresyon fraktürü, altısında epidural hematom ve dördünde ise basınçlı pnemosefalus eşlik etmekteydi.

BULGULAR: Rinore, en sık görülen semptom olup I 5 hastada, otore yedi hastada ve okülore iki hastada saptandı. Rinoresi olan iki hastada ayrıca otore ve okülore de mevcuttu. On iki hasta tek taraflı yaklaşımla, 10 hasta ise bifrontal yaklaşımla opere edildi.

TARTIŞMA: Beyin omurilik sıvısı kaçağı ile prezente olan travma olgularında, konservatif tedavinin aksine yapılan erken cerrahi girişimler BOS kaçağına bağı gelişebilecek komplikasyonların engellenmesinde son derece etkili bir yöntemdir.

Anahtar sözcükler: BOS kaçağı; cerrahi; okülore; otore; rinore; travma.

Ulus Travma Acil Cerrahi Derg 20I5;2I(6):450-456 doi: 10.5505/tjtes.20I5.93236 